American Journal of Pharmacology and Toxicology 2 (4):178-188, 2007

ISSN 1557-4962

(C) 2007 Science Publications

\title{
Anti-Diabetic Activity of a Fraction from Cissus verticillata and Tyramine, its Main Bioactive Constituent, in Alloxan-Induced Diabetic Rats
}

\author{
${ }^{1}$ Cleide de Sousa Lino, ${ }^{1}$ Thiago de Paiva Sales, ${ }^{1}$ Patrícia Bezerra Gomes, ${ }^{1}$ Jeferson Falcão do Amaral, \\ ${ }^{2}$ Francisco S. Oliveira Alexandre, ${ }^{2}$ Edilberto R. Silveira, ${ }^{3}$ Jamile M. Ferreira, ${ }^{3}$ Daniel Freire de Sousa, \\ ${ }^{3}$ Maria Goreti Rodrigues de Queiroz, ${ }^{1}$ Francisca Cléa Florenço de Sousa, ${ }^{4}$ Gerly Anne de Castro Brito, \\ ${ }^{5}$ Salete Maria da Rocha Cipriano Brito and ${ }^{1}$ Glauce Socorro de Barros Viana \\ ${ }^{1}$ Department of Physiology and Pharmacology, \\ ${ }^{2}$ Department of Organic Chemistry, \\ ${ }^{3}$ Department of Clinical and Toxicological Analyses, \\ ${ }^{4}$ Department of Morfology, Federal University of Ceará, Rua Coronel Nunes de Melo 1127, \\ CEP 60430-270, Fortaleza, Brazil \\ ${ }^{5}$ Department of Biochemistry and Pharmacology, Federal University of Piauí, Teresina, Brazil
}

\begin{abstract}
Cissus verticillata (syn. C. sycioides, fam. Vitaceae) is a medicinal plant popularly used in Brazil, for the treatment of diabetes mellitus. The anti-diabetic activity of a fraction from leaves of Cissus verticillata (MSF, methanol soluble fraction), as well as that of tyramine (TYR) were investigated, in the model of alloxan-induced diabetes, in male Wistar rats. The biochemical parameters studied were: serum glucose, triglycerides (TG), total cholesterol (TC) and very low density lipoprotein (VLDL), urea, creatinine, AST and ALT levels. Besides, glycated hemoglobin and liver glycogen concentrations were also determined. The MSF (50 and $100 \mathrm{mg} \mathrm{kg}^{-1}$, p.o.), tyramine (1 and $2 \mathrm{mg} \mathrm{kg}^{-1}$, p.o.), glibenclamide (GLI $5 \mathrm{mg} \mathrm{kg}^{-1}$, p.o.) and metformin (MET, $50 \mathrm{mg} \mathrm{kg}^{-1}$, p.o.) were administered daily, for 5 days, $48 \mathrm{~h}$ after the alloxan injection $\left(40 \mathrm{mg} \mathrm{kg}^{-1}\right.$, i.v.). Drugs were administered alone or associated. Alloxan-diabetic rats showed significant reductions in plasma glucose, triglycerides and total cholesterol, after the treatment with the MSF, tyramine and glibenclamide, as compared to diabetic controls. The MSF and TYR effects were not potentiated by their association with GLI. Besides, MSF or TYR did not reverse DZ-induced hyperglycemia. However, MSF and TYR effects were significantly potentiated by MET, suggesting that these drugs act by a mechanism similar to that of MET. The other biochemical parameters were unaltered. The treatment of diabetic animals with the MSF increased the number of pancreatic beta cells. TYR also decreased the concentration of glycated $\mathrm{Hb}$. While a $61 \%$ decrease in glycogen concentration was observed in diabetic controls, a total and partial recoveries of alloxan effects were seen after treatment of diabetic animals with the MSF (100 mg kg-1 p.o.) and measurements carried out 2 and $24 \mathrm{~h}$ after amyloglicosidase addition, respectively. In conclusion, our results showed that the MSF and TYR, when administered by gavage for 5 days, may reduce glucose, TG and TC levels by a mechanism at least in part similar to that of MET. These results point to the insulin-like effects of C. verticillata, probably due to the presence of tyramine in the plant.
\end{abstract}

Key words: $C$. verticilllata, glucose, triglycerides, total cholesterol, tyramine, anti-diabetic activity

\section{INTRODUCTION}

Diabetes mellitus is a group of syndromes characterized by hyperglycemia, altered metabolism of lipids, carbohydrates and proteins and an increased risk of complications from vascular diseases ${ }^{[1]}$. Several medicinal plants are popularly used in Brazil and elsewhere for the treatment of diabetes and among them are those belonging to the genus Bauhinia, Momordica, Eugenia and Cissus ${ }^{[2,3,4]}$.

Cissus verticillata syn. C. sicyoides (Vitaceae), species studied in the present research, is a medicinal plant

Corresponding Author: Glauce Socorro de Barros Viana, Departamento de Fisiologia e Farmacologia, Universidade Federal do Ceará, Rua Cel. Nunes de Melo, 1127 60.430-270 Fortaleza Brazil 
popularly known in Brazil as cipó-pucá, anil-trepador, cortina, or insulina ${ }^{[4,5,6]}$. Leaf decoctions from $C$. verticillata, called elsewhere as princess vine, are taken as a popular remedy for diabetes in Brazil, where it is also known as vegetal insulin, as well as for other diseases, including rheumatism, epilepsy and stroke ${ }^{[7]}$.

Analgesic and anti-inflammatory effects were detected in C. quadrangularis ${ }^{[8]}$ (Panthong et al., 2006), while analgesic activity was also observed by us in the aqueous exctract and methanol soluble fraction prepared from the fresh leaves of Cissus verticillata $^{[9,10]}$. Furthermore, a very recent study ${ }^{[11]}$ reported that the methanol extract of $C$. quadrangularis possesses peripheral as well as central analgesic effects.

Several substances were isolated from the genus Cissus. Thus, Beltrame reported the isolation of a new coumarin glycoside in the aerial parts of $C$. verticillata, together with a known coumarin, two flavonoids and two steroids ${ }^{[6,12]}$. Furthermore, luteonin, kaempferol and luteonin-3-sulphate were also isolated from the aqueous extract after acid hydrolysis ${ }^{[13]}$.

Recently, tyramine was isolated as a new substance from $C$. verticillata, at the Organic Chemistry Laboratory of the Federal University of Ceará (Brazil) ${ }^{[14]}$. Many studies have found that tyramine administration to diabetic rats increases glucose disposal and reduces hyperglycemia, an effect occurring even at doses that have little effect on cardiovascular variables and for this reason it has been suggested as a possible treatment for diabetes ${ }^{[15,16]}$.

There are only a few reports on the effects of $C$. verticillata and their constituents ${ }^{[6,7,12,13]}$ in the literature, some of them presenting contradictory or unsuccessful results ${ }^{[12]}$. In a previous study ${ }^{[17]}$, we showed that a semi-purified fraction from $C$. verticillata presents hypoglicemic and hypolipidemic activities, in the model of alloxan-induced diabetes in rats. In the present study, we further investigate the effects of the daily oral treatment for 5 days of alloxan-diabetic rats, with a methanol soluble fraction from $C$. verticillata leaves, as compared to its main active constituent, tyramine, on the serum glucose as well as on other biochemical parameters. The effects of the drugs on pancreatic beta cells and on glycated HB levels as well as on hepatic glycogen contents were also investigated, attempting to clarify the mechanism of the hypoglycemic action of this medicinal species.

\section{MATERIALS AND METHODS}

Plant: Fresh leaves of Cissus verticillata were harvested from the Prof. Francisco José de Abreu Matos Medicinal Plants Garden, at the Federal
University of Ceará. Voucher specimens (No.32240), identified at Kew Garden, UK, are deposited at the Prisco Bezerra Herbarium, Federal University of Ceará, Fortaleza, Brazil.

Methanol soluble fraction preparation (MSF): A three hundred gram aliquot of fresh leaves from Cissus verticillata was submitted to decoction with $500 \mathrm{~mL}$ (twice) of $\mathrm{H}_{2} \mathrm{O}$, for $5 \mathrm{~min}$. The procedure was repeated three more times to yield a $4 \mathrm{~L}$ solution, from a total of $1.2 \mathrm{~kg}$ of leaves. After lyophilization, $29.5 \mathrm{~g}$ of a light brown solid residue was obtained, which in turn was stirred for $30 \mathrm{~min}$ with $50 \mathrm{~mL}$ of methanol (twice) to afford $15.67 \mathrm{~g}$ of a viscous brown residue, after methanol rotoevaporation (MSF) and $11.35 \mathrm{~g}$ of the methanol insoluble residue (MIR). Among all the fractions tested for anti-diabetic activity, the most active one was the MSF and, for this reason, it was chosen for further analyses.

Isolation of tyramine (present in $C$. verticillata leaves) from the MSF: MSF $(5.1 \mathrm{~g})$ dissolved in $\mathrm{MeOH}$ and submitted to gel permeation over Sephadex LH-20 (100 g) on a $500 \mathrm{~mL}$ glass column $(5 \mathrm{~cm}$ diameter), by elution with $\mathrm{MeOH}$, resulted in 24 fractions $(9 \mathrm{~mL}$ each), followed by two larger fractions (125 and $250 \mathrm{~mL}$ ) and finally by a $500 \mathrm{~mL}$ fraction eluted with $\mathrm{MeOH} / \mathrm{H}_{2} \mathrm{O}$ 1:1. After TLC comparison, three major fractions were obtained by pooling the similar fractions: $\mathrm{CvMsF}_{8-12}(1.23 \mathrm{~g}), \mathrm{CvMsF}_{13-18}(1.54$ g) and $\mathrm{CvMsF}_{19-24}(1.01 \mathrm{~g}) .{ }^{1} \mathrm{H}$ NMR (500 MHz, $\mathrm{MeOD}$ ) analysis of all major fractions revealed the presence of a major compound in $\mathrm{F}_{19-24}$ that was later designated (tyramine rich fraction (TRF). Besides tyramine characteristic pair of doublets in the aromatic region (6.77 and $7.10 \mathrm{ppm}, \mathrm{J} 8.4 \mathrm{~Hz}$ ) and the pair of triplets in the aliphatic region (2.87 and $3.12 \mathrm{ppm})$, several signals between 3.3 and $4.3 \mathrm{ppm}$ followed by doublets at 4.5 and $5.1 \mathrm{ppm}$ were indicative of the presence of sugar components. TRF was rechromatographed on Sephadex LH-20 by elution with $\mathrm{MeOH}$ to yield 12 fractions $(9 \mathrm{~mL}$ each) that were compared by TLC and pooled by similarity. $\mathrm{F}_{6-8}(750$ $\mathrm{mg}$ ) was redissolved in $\mathrm{MeOH}$ and, then, EtOAc was added dropwise until the formation of a light yellow precipitate. Filtration afforded $390 \mathrm{mg}$ of tyramine (2- $p$ hydroxiphenylethylamine) identical to the standard tyramine, after TLC co-cromatography and ${ }^{1} \mathrm{H}$ and ${ }^{13} \mathrm{C}$ NMR spectral analyses (157.8, 116.9, 130.9, 128.6, 42.4 and $33.9 \mathrm{ppm})$. These methods were performed either separately with tyramine from TRF and standard tyramine, or in a 1:1 mixture. The process was repeated 4 times in order to provide enough material for all pharmacological assays. 
Drugs: Alloxan monohydrate, tyramine hydrochloride and diazoxide were obtained from Sigma Chemical Co. (St.Louis, MO, USA), glibenclamide, from Aventis Brasileiro Ltda. (GO, Brazil) and metformin, from Merck. All other drugs were of analytical grade and dissolved in distilled water for oral administration, before use.

Animals: Male Wistar rats (180-250 g) from the Animal House of the Federal University of Ceará were housed in standard environmental conditions $\left(22 \pm 1 \uparrow^{\circ} \mathrm{C}\right.$, humidity $60 \pm 5 \%, 12 \mathrm{~h}$ light: $12 \mathrm{~h}$ dark cycle), with free access to a standard commercial diet and water ad libitum. Experiments were performed according to the Guide for the Care and Use of Laboratory Animals, from the US Department of Health and Human Services, Institute of Laboratory Animal Resources, Washington DC, 1985. Experimental protocol: Animals were divided into 8 groups of 5-38 animals each. The first group, untreated, was named the normal group (NC). Diabetic groups (untreated and treated) fasted for at least $16 \mathrm{~h}$, received alloxan (ALX, $40 \mathrm{mg} \mathrm{kg}^{-1}$ ) through the penile vein. The diabetic state in these groups was assessed by measurements of the serum glucose levels, $48 \mathrm{~h}$ later, when around $40 \%$ deaths were registered due to the alloxan toxicity. Animals that presented glucose levels lower than $200 \mathrm{mg} \mathrm{dL}^{-1}$ were rejected. The studied groups were: normal (NC), diabetic plus distilled water (DC), diabetic plus methanol soluble fraction, 50 and $100 \mathrm{mg} \mathrm{kg}^{-1}$ (MSF 50 and MSF 100), diabetic plus glibenclamide $5 \mathrm{mg} \mathrm{kg}^{-1}$ (GLI 5), diabetic plus standard tyramine 1 and $2 \mathrm{mg}$ $\mathrm{kg}^{-1}$ (TYR 1 or 2) and diabetic plus glibenclamide $5 \mathrm{mg}$ $\mathrm{kg}^{-1}$ (GLI 5) alone or associated with tyramine. Besides, other diabetic rat group treated with metformin $50 \mathrm{mg} \mathrm{kg}^{-1}$ (MET) alone or associated with tyramine were also included. Animals were treated orally for 5 days (unless otherwise specified), $48 \mathrm{~h}$ after the alloxan-induced diabetes. Blood samples were collected just prior and five days after treatments.

Determination of biochemical parameters in rat serum: Blood from the retro-orbital plexus was collected and centrifuged at $3000 \mathrm{rpm}$ for $10 \mathrm{~min}$ and the glucose level was determined by the glucose oxidase-peroxidase enzymatic method (Labtest, Brazil). Concentrations of serum total cholesterol (TC), triglycerides (TG) and very low density lipoprotein (VLDL) levels were measured by standard enzymatic colorimetric methods (Trinder 1969) in the spectrophotometer, model Selectra II, from Winner. AST, ALT, urea and creatinine levels were also determined by standard procedures, according to the manufacturer's instructions (Labtest, Brazil).

Effects of the MSF, TYR, GLI and diazoxide (DZ), alone or associated, on DZ-induced hyperglycemia: Groups of 6 male Wistar rats (150-250 g) were divided into normal controls (NC), MSF (100 mg/kg), GLI (5 $\mathrm{mg} / \mathrm{kg})$, TYR $\left(2 \mathrm{mg} \mathrm{kg}^{-1}\right), \mathrm{DZ}\left(60 \mathrm{mg} \mathrm{kg}^{-1}\right)$ and the associations of MSF 100+DZ 60, GLI 5+DZ 60, TYR $2+\mathrm{DZ} 60$. Firstly, animals were treated orally with each drug and their blood collected before and 30, 60 and $120 \mathrm{~min}$ after the drugs administration. In another experiment, animals were treated with the drugs and injected with DZ, 30 min later. Blood samples were collected from the retro-orbital plexus, in tubes containing separation gel, before and 30,60 and 120 min after DZ administration. Then, the blood was centrifuged at 3,000 rpm, for $10 \mathrm{~min}$ and samples used for glucose determination by the glucose-oxidase method (Labtest, Brazil).

In vitro determination of glycated hemoglobin $(\mathrm{Hb})$ : Blood was collected from the abdominal aorta of nondiabetic $12 \mathrm{~h}$ fasted rats and distributed in tubes containing EDTA $\left(10 \mathrm{~g} \mathrm{dL}^{-1}\right)$. After centrifugation at $3,000 \mathrm{rpm}$, the supernatant was discarded and cells, filtered, washed $(0.15 \mathrm{M} \mathrm{NaCl}, 1: 10,3 \times$ times $)$ and centrifuged at 3,000 rpm, 5 min each time. The cell suspension was washed twice more, transferred to tubes and phosphate buffer $0.01 \mathrm{M}, \mathrm{pH} 7.4$, containing gentamycin $\left(20 \mathrm{mg} \mathrm{dL}^{-1}\right)$ and $\mathrm{CCl} 4$ (1:2:0.5) was added. The mixture was centrifuged at 3,000 rpm, 5 min and the total $\mathrm{Hb}$ concentration in the supernatant, determined spectrophotometrically at $540 \mathrm{~nm}$. The mixture was diluted in $0.01 \mathrm{M}$ phosphate buffer, $\mathrm{pH}$ 7.4 , to obtain a solution containing $8 \mathrm{~g} \mathrm{dL}^{-1}$ of $\mathrm{Hb}$. Tubes with the hemoglobin solution (final concentration of $\left.4 \mathrm{~g} \mathrm{dL}^{-1}\right)$, gentamycin $\left(20 \mathrm{mg} \mathrm{dL}^{-1}\right)$ and $1 \mathrm{~mL}$ of phosphate buffer, containing $50 \mathrm{mM}$ glucose (controls), MSF, TYR or quercetin $(50 \mu \mathrm{g}$ $\mathrm{mL}^{-1}$, each) were incubated for $48 \mathrm{~h}$ (in the dark and at room temperature). After incubation, samples were treated with $1 \mathrm{M}$ boric acid to remove the unstable fraction of the glycated hemoglobin and submitted to ionic exchange chromatography for glycated hemoglobin determination.

Hepatic glycogen determination: Alloxan-induced diabetic rats were treated with MSF $\left(100 \mathrm{mg} \mathrm{kg}^{-1}\right.$, p.o. $)$ or distilled water (DC), for 10 days. Control animals (NC) were also treated with distilled water. In the 10th day, animals were anesthetized with ether, $1 \mathrm{~h}$ after the 
last drug treatment, their livers dissected, washed with saline and samples from all groups were removed and weighted. Then, samples were homogenized in sodium citrate buffer $(0.1 \mathrm{M}, \mathrm{pH} 4.2)$ and $10 \mu \mathrm{L}$ of the homogenate was used to determine free glucose in the tissue. For this assay, $100 \mathrm{mg}$ liver pieces in $10 \mathrm{~mL}$ buffer were used, followed by the addition to the homogenate of $1 \mathrm{mg}$ of powder amyloglicosidase per $\mathrm{ml}$ of buffer. The assay mixture was left at room temperature, from 2-24 h. Samples $(10 \mu \mathrm{L})$ were then used to determine the total glucose concentration, by the glucose oxidase method, according to the manufacturer's instructions (Labtest, Brazil). Results were expressed as $\mathrm{mg}$ glycogen/100 $\mathrm{mg}$ tissue.

Histological studies: Diabetic animals were sacrificed at the 5th day after treatment and their pancreas dissected, washed with saline and placed in buffered formalin, followed by a 70\% alcohol solution, $24 \mathrm{~h}$ later. Tissue samples were fixed in formalin and embedded in paraffin for light microscopy examination of HE sections.

Statistical analyses: All results are presented as mean_S.E.M. Data was analyzed by ANOVA followed by Student-Neuman-Keuls as the post hoc test and Student's t-test for paired observations. Results were considered significant at $\mathrm{p}<0.05$.

\section{RESULTS AND DISCUSSION}

The treatment of diabetic rats with MSF, at the doses of 50 and $100 \mathrm{mg} \mathrm{kg}^{-1}$, p.o., significantly decreased glycemia in 28 and $46 \%$, respectively. While TC levels were unchanged, TG and VLDL levels also decreased by 44 and $54 \%$, with both doses, as compared to values before the treatment. TYR 1 and GLI 5 (an oral hypoglycemic drug of the sulfonylurea class, used as standard) treatments of diabetic rats decreased levels of glycemia, TG and VLDL in 41 and $57 \%$ and in 45 and $54 \%$, respectively, as compared to values before the treatment. While TYR 2 decreased levels of glycemia, TG and VLDL in 33 and $57 \%$. A similar picture was observed after treatment of diabetic rats with the association of GLI 5 + TYR 1 (32 and $49 \%$ decreases of glycemia and TG levels, as compared to values before the treatment) (Table 1 and 2).

Although diabetic rats showed a $28 \%$ increase in urea values, these values came close to normal ones, 5 days later. However, the increase in creatinine levels was maintained after this period of time (3.6 and 3 times increases, respectively). Urea values in diabetic rats before treatment with MSF (50 and $100 \mathrm{mg} \mathrm{kg}^{-1}$,
Table 1: Glycemia and serum lipid profiles $\left(\mathrm{mg} \mathrm{dL}^{-1}\right)$ in normal controls (NC), alloxan-induced diabetic rats (DC) and diabetic rats, before and after treatment with the methanol soluble fraction from Cissus verticillata (MSF), tyramine (TYR), glibenclamide (GLI) and the combination of glibenclamide plus tyramine (GLI + TYR)

\begin{tabular}{lll}
\hline $\begin{array}{l}\text { Groups } \\
\left(\mathrm{mg} \mathrm{kg}^{-1}, \text { p.o }\right)\end{array}$ & Glycemia $\left(\mathrm{mg} \mathrm{dL}^{-1}\right)$ & \\
\hline NC & Before & After \\
DC & $93.9 \pm 2.70(10)$ & $97.8 \pm 4.55$ \\
MSF 50 & $377.6 \pm 14.11(38)^{*}$ & $369.3 \pm 19.34^{*}$ \\
MSF 100 & $410.7 \pm 32.29(20)^{*}$ & $295.5 \pm 26.04^{* *}$ \\
TYR 1 & $354.7 \pm 21.29(22)^{*}$ & $191.7 \pm 19.71^{* *}$ \\
TYR 2 & $373.5 \pm 27.15(13)^{*}$ & $219.9 \pm 14.25^{* *}$ \\
GLI 5 & $257.3 \pm 22.96(07)^{*}$ & $171.9 \pm 26.33^{* *}$ \\
GLI 5+TYR 1 & $385.4 \pm 17.63(12)^{*}$ & $210.3 \pm 30.67^{* *}$ \\
\hline
\end{tabular}

Values represent mean \pm SEM for the number of animals in parentheses. Diabetic rats were treated with distilled water (DC) or MSF (50 and $100 \mathrm{mg} \mathrm{kg}^{-1}$ ), TYR ( 1 and $\left.2 \mathrm{mg} \mathrm{kg}^{-1}\right)$, GLI (5 mg kg${ }^{-1}$ ) or the association of GLI $\left(5 \mathrm{mg} \mathrm{kg}^{-1}\right)$ plus TYR $\left(1 \mathrm{mg} \mathrm{kg}^{-1}\right)$, orally for 5 days. Before and After = diabetic animals before and after treatment. ${ }^{*} \mathrm{p}<0.05$ as compared to normal controls (NC). The data were analyzed by ANOVA and Student-Newman-Keuls as the post hoc test. $* \mathrm{p}<0.01$ when compared to the same group before treatment (Student's paired t test)

p.o.) increased in 80 and $134 \%$ and decreased to 16 and $25 \%$ after treatment. Similar data were observed in creatinine levels which decreased from 2.6-1.2 times and from 1.9 times to normal ones, after diabetic rats treatment with the MSF doses of 50 and $100 \mathrm{mg} \mathrm{kg}^{-1}$, respectively. While TYR 1 and TYR 2 treatments of diabetic rats did not significantly altered urea levels, they decreased creatinine levels to 1.4 and 1.5 times, as related to normal controls. As far as AST and ALT levels are concerned, the only significant change was that seen with the group of diabetic animals treated with the association of GLI 5+TYR 1 where decreases of 48 and $22 \%$ respectively were observed, as compared to diabetic controls (Table 3 ).

Diazoxide (DZ) is an antihypertensive drug that increases blood glucose by decreasing insulin release levels and opening of $\mathrm{K}^{+}$channels and, in this sense, it presents a mechanism of action opposed to that of GLI. Our data (Table 4) showed that DZ significantly increased glycemia, after 60 and $120 \mathrm{~min}$. MSF or TYR alone did not alter the blood glucose levels during this period (up to $120 \mathrm{~min}$ ) nor reversed the DZ hyperglycemic effect. On the other hand, while GLI did not show any effect per se, it significantly reversed the hyperglycemic effect of $\mathrm{DZ}$, bringing values to normal levels. These experiments showed that both the MSF and TYR probably do not act by the same mechanism as GLI. In order to clarify the mechanism of action of the hypoglycemic effect of $C$. verticillata, biochemical parameters in sera of diabetic rats treated with 
Am. J. Pharm. \& Toxicol., 2 (4):178-188, 2007

Table 2: Total cholesterol (TC), triglycerides (TG) and very low density lipoprotein (VLDL) levels in the serum from normal (NC) and alloxaninduced diabetic rats (DC), before and after the treatment with the methanol soluble fraction from Cissus verticillata (MSF), tyramine (TYR), glibenclamide (GLI) and the combination of glibenclamide plus tyramine (GLI + TYR)

\begin{tabular}{|c|c|c|c|c|c|c|}
\hline \multirow[t]{2}{*}{ Group } & \multicolumn{2}{|l|}{$\mathrm{TC}$} & \multicolumn{2}{|l|}{ TG } & \multicolumn{2}{|c|}{ VLDL $\left(\mathrm{mg} \mathrm{dL}^{-1}\right)$} \\
\hline & Before & After & Before & After & Before & After \\
\hline $\mathrm{NC}$ & $\begin{array}{l}64.1 \pm 5.38 \\
(10)\end{array}$ & $58.7 \pm 3.93$ & $\begin{array}{l}64.9 \pm 9.17 \\
(12)\end{array}$ & $79.8 \pm 10.25$ & $\begin{array}{l}12.8 \pm 1.74 \\
(12)\end{array}$ & $16.0 \pm 2.05$ \\
\hline DC & $\begin{array}{l}78.2 \pm 4.99 \\
(20)^{*}\end{array}$ & $62.5 \pm 3.53$ & $\begin{array}{l}184.2 \pm 13.51 \\
(31)^{*}\end{array}$ & $145.0 \pm 12.9^{*}$ & $\begin{array}{l}36.8 \pm 2.70 \\
(31)^{*}\end{array}$ & $28.8 \pm 2.64 *$ \\
\hline MSF 50 & $\begin{array}{l}74.4 \pm 4.61 \\
(19)^{*}\end{array}$ & $60.2 \pm 3.82 * *$ & $\begin{array}{l}177.0 \pm 17.47 \\
(13)^{*}\end{array}$ & $99.5 \pm 5.97 * *$ & $\begin{array}{l}35.4 \pm 3.49 \\
(13)^{*}\end{array}$ & $19.9 \pm 1.19 * *$ \\
\hline MSF 100 & $\begin{array}{l}64.4 \pm 2.80 \\
\text { (9) }\end{array}$ & $53.3 \pm 3.89 * *$ & $\begin{array}{l}152.4 \pm 17.76 \\
(29)^{*}\end{array}$ & $70.5 \pm 4.67 * *$ & $\begin{array}{l}30.5 \pm 3.55 \\
(29)^{*}\end{array}$ & $14.1 \pm 0.93 * *$ \\
\hline TYR 1 & $\begin{array}{l}68.4 \pm 5.65 \\
(14)\end{array}$ & $60.3 \pm 7.23$ & $\begin{array}{l}228.8 \pm 16.78 \\
(19)^{*}\end{array}$ & $98.8 \pm 8.96^{* *}$ & $\begin{array}{l}45.8 \pm 3.40 \\
(19)^{*}\end{array}$ & $19.8 \pm 1.79 * *$ \\
\hline TYR 2 & $\begin{array}{l}53.3 \pm 2.63 \\
(12)\end{array}$ & $43.9 \pm 1.36^{* *}$ & $\begin{array}{l}149.4 \pm 11.86 \\
(10)^{*}\end{array}$ & $64.2 \pm 6.50 * *$ & $\begin{array}{l}29.9 \pm 2.38 \\
(10)^{*}\end{array}$ & $12.8 \pm 1.30 * *$ \\
\hline GLI 5 & $\begin{array}{l}76.9 \pm 8.08 \\
(15)^{*}\end{array}$ & $53.2 \pm 4.70 * *$ & $\begin{array}{l}167.7 \pm 20.15 \\
(16)^{*}\end{array}$ & $76.9 \pm 9.70^{* *}$ & $\begin{array}{l}33.5 \pm 4.03 \\
(16)^{*}\end{array}$ & $15.4 \pm 1.96^{* *}$ \\
\hline GLI 5 + TYR 1 & $\begin{array}{l}81.5 \pm 5.09 \\
(18)^{*}\end{array}$ & $67.8 \pm 4.63 * *$ & $\begin{array}{l}262.5 \pm 28.13 \\
(6)^{*}\end{array}$ & $134.0 \pm 24.60 * *$ & $\begin{array}{l}52.3 \pm 5.54 \\
(6)^{*}\end{array}$ & $26.8 \pm 4.92 * *$ \\
\hline
\end{tabular}

TC, TG e VLDL were measured in the serum from NC, DC and diabetic rats, before and after oral treatments for 5 days with MSF (50 and 100 $\mathrm{mg}$ ), TYR (1 and $2 \mathrm{mg}$ ) and GLI (5 mg/kg), alone or associated. Treatments started $48 \mathrm{~h}$ after alloxan-induced diabetes. NC and DC were treated with distilled water. Values represent mean \pm SEM of the number of animals in parenthesis. ${ }^{*} p<0.05$ as compared to NC (ANOVA and StudentNewman-Keuls as the post hoc test), ${ }^{* *} \mathrm{p}<0.05$ as compared to the same group before treatment (Student's paired t test)

Table 3: Urea, creatinine, AST and ALT levels in the serum of normal controls, alloxan-induced diabetic rats and diabetic rats, before and after treatment with the methanol soluble fraction from Cissus verticillata (MSF), tyramine (TYR), glibenclamide (GLI) and the combination of glibenclamide plus tyramine (GLI + TYR)

\begin{tabular}{|c|c|c|c|c|c|}
\hline Group & & $\operatorname{Urea}\left(\mathrm{mg} \mathrm{Dl}^{-1}\right)$ & Creatinine $\left(\mathrm{mg} \mathrm{dL}^{-1}\right)$ & $\operatorname{AST}\left(\mathrm{U} \mathrm{L}^{-1}\right)$ & $\operatorname{ALT}\left(\mathrm{U} \mathrm{L}^{-1}\right)$ \\
\hline \multirow[t]{2}{*}{$\mathrm{NC}$} & B & $\begin{array}{l}38.8 \pm 2.32 \\
(14)\end{array}$ & $\begin{array}{l}0.8 \pm 0.03 \\
(14)\end{array}$ & $\begin{array}{l}97.6 \pm 6.23 \\
(10)\end{array}$ & $\begin{array}{l}57.4 \pm 4.02 \\
(12)\end{array}$ \\
\hline & A & $38.0 \pm 2.26$ & $0.8 \pm 0.03$ & $87.7 \pm 6.54$ & $51.3 \pm 4.95$ \\
\hline \multirow[t]{2}{*}{ DC } & B & $\begin{array}{l}53.7 \pm 4.03 \\
(15)^{*}\end{array}$ & $\begin{array}{l}2.9 \pm 0.19 \\
(15)^{*}\end{array}$ & $\begin{array}{l}126.8 \pm 8.43 \\
(26)\end{array}$ & $\begin{array}{l}58.7 \pm 5.52 \\
(21)\end{array}$ \\
\hline & A & $45.4 \pm 5.07$ & $2.4 \pm 0.10^{*}$ & $118.0 \pm 8.25$ & $58.7 \pm 7.25$ \\
\hline \multirow[t]{2}{*}{ MSF 50} & B & $\begin{array}{l}70.0 \pm 9.03 \\
(8)^{*}\end{array}$ & $\begin{array}{l}2.1 \pm 0.46 \\
(8)^{*}\end{array}$ & $\begin{array}{l}112.5 \pm 7.32 \\
(13)\end{array}$ & $\begin{array}{l}48.0 \pm 3.86 \\
(11)\end{array}$ \\
\hline & A & $59.0 \pm 6.06^{* *}$ & $1.0 \pm 0.14 * *$ & $92.1 \pm 7.50 * *$ & $55.5 \pm 5.35$ \\
\hline \multirow[t]{2}{*}{ MSF 100} & B & $\begin{array}{l}90.8 \pm 7.18 \\
(8)^{*}\end{array}$ & $\begin{array}{l}1.5 \pm 0.27 \\
(8)^{*}\end{array}$ & $\begin{array}{l}127.8 \pm 8.26 \\
(16)\end{array}$ & $\begin{array}{l}54.0 \pm 5.08 \\
(13)\end{array}$ \\
\hline & A & $67.8 \pm 6.40 * *$ & $0.9 \pm 0.13 * *$ & $119.8 \pm 8.89$ & $49.4 \pm 5.75$ \\
\hline \multirow[t]{2}{*}{ TYR 1} & B & $\begin{array}{l}46.5 \pm 4.40 \\
(10)^{*}\end{array}$ & $\begin{array}{l}2.5 \pm 0.21 \\
(13)^{*}\end{array}$ & $\begin{array}{l}104.1 \pm 8.72 \\
(21)\end{array}$ & $\begin{array}{l}46.0 \pm 3.15 \\
(21)\end{array}$ \\
\hline & A & $33.6 \pm 5.13 * *$ & $1.8 \pm 0.17 * *$ & $88.3 \pm 10.02$ & $38.0 \pm 2.82$ \\
\hline \multirow[t]{2}{*}{ TYR 2} & B & $\begin{array}{l}63.4 \pm 3.73 \\
(10)^{*}\end{array}$ & $\begin{array}{l}1.8 \pm 0.29 \\
(10)^{*}\end{array}$ & $\begin{array}{l}122.9 \pm 12.1 \\
(12)\end{array}$ & $\begin{array}{l}52.3 \pm 4.06 \\
(12)\end{array}$ \\
\hline & A & $53.8 \pm 3.10$ & $1.2 \pm 0.15 * *$ & $113.7 \pm 12.31$ & $45.3 \pm 4.41$ \\
\hline \multirow[t]{2}{*}{ GLI 5} & B & $\begin{array}{l}67.6 \pm 6.55 \\
(10)^{*}\end{array}$ & $\begin{array}{l}1.4 \pm 0.15 \\
(8)\end{array}$ & $\begin{array}{l}125.3 \pm 9.25 \\
(8)\end{array}$ & $\begin{array}{l}53.7 \pm 5.52 \\
(8)\end{array}$ \\
\hline & A & $60.9 \pm 3.60$ & $1.0 \pm 0.07 * *$ & $111.8 \pm 6.91$ & $48.4 \pm 5.96$ \\
\hline \multirow[t]{2}{*}{ GLI 5+TYR 1} & B & $\begin{array}{l}90.5 \pm 5.88 \\
(12)^{*}\end{array}$ & $\begin{array}{l}1.5 \pm 0.20 \\
(8)^{*}\end{array}$ & $\begin{array}{l}91.3 \pm 6.99 \\
(8)\end{array}$ & $\begin{array}{l}37.3 \pm 2.07 \\
(8)\end{array}$ \\
\hline & A & $92.1 \pm 8.83$ & $0.9 \pm 0.04 * *$ & $47.3 \pm 4.60 *, * *$ & $29.0 \pm 0.90 * *$ \\
\hline
\end{tabular}

Values represent mean \pm SEM for the number of animals in parentheses. $\mathrm{NC}=$ non-diabetic controls. Diabetic animals were treated, orally for 5 days, with distilled water (DC) or MSF (50 and $\left.100 \mathrm{mg} \mathrm{kg}^{-1}\right)$, TYR (1 and $\left.2 \mathrm{mg} \mathrm{kg}^{-1}\right)$ and GLI $\left(5 \mathrm{mg} \mathrm{kg}^{-1}\right)$, alone or associated. B and A= diabetic animals before and after treatments. ${ }^{*} \mathrm{p}<0.05$ as compared to NC (ANOVA and Student-Newman-Keuls as the post hoc test; ${ }^{* *} \mathrm{p}<0.05$ as compared to the same group before treatment (Student's paired t test)

tyramine, metformin (an oral hypoglycemic drug of the biguanide class) and their association were determined. We showed that TYR ( 1 and $2 \mathrm{mg} \mathrm{Kg}^{-1}$, p.o.) decreased in a dose-dependent manner ( 35 and $43 \%$ decreases, respectively) glycemia values, as compared to diabetic controls, while metformin caused a $49 \%$ decrease. The association MET 50+TYR 2 decreased the glycemia in $73 \%$ and MET $50+$ TYR 1 brought glycemia values to 
Am. J. Pharm. \& Toxicol., 2 (4):178-188, 2007

Table 4: Evaluation of the methanol soluble fraction (MSF) from Cissus verticillata, diazoxide (DZ), tyramine (TYR), glibenclamide (GLI) and the associations of MSF + DZ, TYR + DZ and GLI + DZ, on diazoxide glycemic curves, in rats

\begin{tabular}{lllll}
\hline Group & Time $(\min ) 03060120$ & & & \\
\hline NC & $88.5 \pm 2.55$ & $91.0 \pm 3.72$ & $98.3 \pm 6.64$ & $99.0 \pm 5.36$ \\
DZ 60 & $63.4 \pm 3.27$ & $116.2 \pm 5.24$ & $164.2 \pm 17.01^{*}$ & $211.2 \pm 16.90^{*}$ \\
MSF 100 & $67.3 \pm 1.78$ & $85.8 \pm 4.18$ & $86.5 \pm 3.69$ & $102.7 \pm 5.32$ \\
MSF 100+DZ 60 & $55.7 \pm 1.80$ & $112.2 \pm 6.02$ & $147.3 \pm 4.29^{*}$ & $203.3 \pm 9.60^{*}$ \\
TYR 2 & $107.0 \pm 3.30$ & $88.5 \pm 3.40$ & $109.2 \pm 5.50$ & $115.5 \pm 4.37$ \\
TYR 2+DZ 60 & $62.2 \pm 3.63$ & $117.0 \pm 6.57$ & $166.1 \pm 21.1 *$ & $221.7 \pm 35.42 *$ \\
GLI 5 & $67.3 \pm 3.16$ & $65.8 \pm 5.06$ & $60.7 \pm 5.54$ & $70.5 \pm 6.41$ \\
GLI 5+DZ 60 & $76.0 \pm 3.73$ & $74.0 \pm 7.75^{* *}$ & $99.0 \pm 9.79^{* *}$ & $110.0 \pm 14.43 * *$ \\
\hline
\end{tabular}

Values represent mean \pm SEM from 6 rats per group, fasted for $12 \mathrm{~h}$. $\mathrm{NC}=$ normal controls. Glycemia was evaluated before (zero time, $\mathrm{T}=0$ ). Then, animals were pretreated orally with MSF $\left(100 \mathrm{mg} \mathrm{kg}^{-1}\right)$, TYR $\left(2 \mathrm{mg} \mathrm{kg}^{-1}\right)$ and GLI $\left(5 \mathrm{mg} \mathrm{kg}^{-1}\right)$ and 30 min later with DZ $\left(60 \mathrm{mg} \mathrm{kg}{ }^{-1}\right.$, i.p.). Glycemia was measured at 30,60 and 120 min after the administration of the drugs, alone or associated with DZ.*p $<0.05$ as related to normal controls (NC), at each observation time, ${ }^{* *} \mathrm{p}<0.05$ associated drugs as compared to DZ (ANOVA and Student-Newman-Keuls as the post hoc test)

Table 5: Effects of tyramine (TYR), the main active constituent of the methanol soluble fraction (MSF) from Cissus verticillata, alone or associated with metformin (MET), on glycemia, in aloxan-induced diabetic rats

\begin{tabular}{lll}
\hline & Glycemia $\left(\mathrm{mg} \mathrm{dl}^{-1}\right)$ & \\
Group & Before treatment & After treatment \\
\hline NC & $72.9 \pm 2.30(08)$ & $80.8 \pm 3.37$ \\
DC & $328.2 \pm 22.02(18)^{*}$ & $335.1 \pm 18.87^{*}$ \\
TYR & $1324.7 \pm 18.12(17)^{*}$ & $211.3 \pm 15.23^{* *}$ \\
TYR & $2259.5 \pm 17.57(11)^{*}$ & $148.0 \pm 28.55^{* *}$ \\
MET & $50315.6 \pm 18.70(14)^{*}$ & $160.6 \pm 23.82^{* *}$ \\
MET 50+TYR 1 & $308.0 \pm 24.03(08)^{*}$ & $105.9 \pm 17.12^{* *}$ \\
MET 50+ TYR 2 & $409.8 \pm 27.92(08)^{*}$ & $111.3 \pm 27.93^{* *}$ \\
\hline Values represent mean \pm SEM for the number of animals in \\
parentheses. NC = normal controls. Diabetic animals were treated, \\
orally for 5 days, with distilled water (DC), MET (50 mg kg $\left.{ }^{-1}\right)$, or \\
TYR (1 and 2 mg kg $\left.{ }^{-1}\right)$, alone or associated. Before and After $=$ \\
diabetic animals before and after treatments.*p<0.05 as compared to \\
NC (ANOVA and Student-Newman-Keuls as the post hoc \\
test) ${ }^{* *}<0.05$ as compared to the same group before treatment \\
(Student's paired t test)
\end{tabular}

normal ones, suggesting a potentiation of the TYR effect by MET 50 (Table 5).

Alloxan-induced diabetes per se did not significantly alter total cholesterol levels. The treatment of diabetic animals with TYR (1 and $2 \mathrm{mg} \mathrm{kg}^{-1}$, p.o.) or MET decreased cholesterol values which ranged from 23,28 to $37 \%$, as compared to values before the treatment. The association of TYR at the lower dose with MET decreased those values even more (34 and $26 \%$ decrease), as compared to values before the treatment. However, alloxan-induced diabetes increased drastically triglycerides levels (2.2-1.3 times). While these values after 5 days were still high, the treatment with TYR alone or associated with MET brought them closer to normal values. A similar picture was seen in VLDL levels that were drastically increased after diabetes induction and went down to normal values after treatment with TYR, MET and their association. VLDL values in diabetic rats without treatment (DC) were still high after 5 days (Table 6 ).
Alloxan-induced diabetes significantly increased urea as well as creatinine levels (153-101\% and 7.8-6.3 times, respectively) (Table 7). However, while creatinine levels in diabetic rats remained higher 5 days later (7.8 and 6.3 times higher), as compared to normal controls, these values were significantly reduced from 26, 39 and 52, after treatment with TYR 1 (before: 6.5; after: 4.8 times), TYR 2 (before: 5.8; after: 3.5 times) and MET 50 (before: 7.8 times; after: 3.8 times). Urea values in diabetic rats before treatment with TYR (1 and $2 \mathrm{mg} \mathrm{kg}^{-1}$, p.o.) and MET 50 increased in 114, 200 and $96 \%$ and decreased to 26,16 and $31 \%$ after treatment The association (MET 50+TYR 1 and MET $50+$ TYR 2) decreased the urea levels in 50 and $43 \%$ and creatinine in 57 and $32 \%$ as compared with diabetic rats before treatment. AST and ALT values were not significantly altered by diabetes, at the conditions of the present work. However, AST values in almost all diabetic treated groups were reduced, 5 days later, to around half, as compared to diabetic control values. On the other hand, no significant alteration was noticed in ALT values (Table 7).

Figure 1 shows that the glycogen concentrations were maintained at the same levels when measured in the normal control group, 2 and $24 \mathrm{~h}$ after the amyloglicosidase addition. A $61 \%$ decrease in glycogen concentration was observed in the diabetic control group, as measured at both time points. Total or partial recoveries of alloxan effects were seen, after the treatment of diabetic animals with the MSF $(100 \mathrm{mg}$ $\mathrm{kg}^{-1}$, p.o.), when the glycogen concentration was measured, 2 and $24 \mathrm{~h}$ after amyloglicosidase addition.

Table 8 shows the results of the levels of glycated hemoglobin which were significantly decreased in rat erythrocytes, in the presence of MSF (37\% decrease), TYR ( $40 \%$ decrease) and quercetin, used as a positive standard (51\% decrease). Our data show a similar efficacy among the three drugs used. Alloxan is known to destroy liver beta cells. We showed that the islet total 
Am. J. Pharm. \& Toxicol., 2 (4):178-188, 2007

Table 6: Total cholesterol (TC), triglycerides (TG) and very low density lipoprotein (VLDL) levels, in the serum from normal (NC) and alloxaninduced diabetic rats (DC), before and after treatment with the methanol soluble fraction (MSF) from Cissus verticillata, tyramine (TYR), metformin (MET) and the combination of MET + TYR

\begin{tabular}{|c|c|c|c|c|c|c|}
\hline \multirow[t]{2}{*}{ Group } & \multicolumn{2}{|l|}{$\mathrm{TC}$} & \multicolumn{2}{|l|}{ TG } & \multicolumn{2}{|c|}{$\operatorname{VLDL}\left(\mathrm{mg} \mathrm{dL}^{-1}\right)$} \\
\hline & Before & After & Before & After & Before & After \\
\hline $\mathrm{NC}$ & $\begin{array}{l}61.7 \pm 3.27 \\
(20)\end{array}$ & $72.2 \pm 1.79$ & $\begin{array}{l}64.9 \pm 9.17 \\
(12)\end{array}$ & $79.8 \pm 10.25$ & $12.8 \pm 1.74$ & $16.0 \pm 2.05$ \\
\hline DC & $\begin{array}{l}71.0 \pm 3.05 \\
(18)\end{array}$ & $64.7 \pm 3.14 * *$ & $\begin{array}{l}140.8 \pm 11.89 \\
(15)^{*}\end{array}$ & $106.0 \pm 9.33^{*}$ & $\begin{array}{l}28.2 \pm 2.38 \\
(15)^{*}\end{array}$ & $21.2 \pm 1.87$ \\
\hline TYR 1 & $\begin{array}{l}67.6 \pm 3.25 \\
(15)\end{array}$ & $52.3 \pm 4.17 *, * *$ & $\begin{array}{l}181.4 \pm 14.44 \\
(17)^{*}\end{array}$ & $89.4 \pm 8.77^{* *}$ & $\begin{array}{l}36.3 \pm 2.89 \\
(17)^{*}\end{array}$ & $17.9 \pm 1.75 * *$ \\
\hline TYR 2 & $\begin{array}{l}66.1 \pm 3.07 \\
(11)\end{array}$ & $47.3 \pm 1.69 *, * *$ & $\begin{array}{l}154.0 \pm 11.70 \\
(11)^{*}\end{array}$ & $70.6 \pm 10.62 * *$ & $\begin{array}{l}30.8 \pm 2.34 \\
(11)^{*}\end{array}$ & $14.1 \pm 2.13 * *$ \\
\hline MET 50 & $\begin{array}{l}71.0 \pm 4.72 \\
(14)\end{array}$ & $44.5 \pm 2.84 *, * *$ & $\begin{array}{l}152.8 \pm 15.11 \\
(14)^{*}\end{array}$ & $79.7 \pm 5.62 * *$ & $\begin{array}{l}30.6 \pm 3.02 \\
(14)^{*}\end{array}$ & $16.0 \pm 1.12^{* *}$ \\
\hline MET50+TYR 1 & $\begin{array}{l}79.4 \pm 7.87 \\
(8)^{*}\end{array}$ & $52.4 \pm 6.50^{*, * *}$ & $\begin{array}{l}166.8 \pm 14.13 \\
(8)^{*}\end{array}$ & $92.1 \pm 9.23^{* *}$ & $\begin{array}{l}33.4 \pm 2.83 \\
(8)^{*}\end{array}$ & $18.4 \pm 1.86^{* *}$ \\
\hline MET50+TYR 2 & $\begin{array}{l}63.7 \pm 3.98 \\
(8)\end{array}$ & $47.3 \pm 2.34 *, * *$ & $\begin{array}{l}209.3 \pm 13.38 \\
(8)^{*}\end{array}$ & $76.6 \pm 5.24 * *$ & $\begin{array}{l}41.9 \pm 2.68 \\
(8)^{*}\end{array}$ & $15.3 \pm 1.05^{* *}$ \\
\hline
\end{tabular}

TC, TG and VLDL were measured in rat serum from NC, DC and diabetic rats before and after oral treatments for 5 days with tyramine (TYR 1 and $2 \mathrm{mg}^{-1}$ po) or Metformin (MET $50 \mathrm{mg} \mathrm{kg}^{-1}$ po), alone or associated. Treatments started $48 \mathrm{~h}$ after alloxan-induced diabetes. Normal and diabetic controls were treated with distilled water. Values represent mean \pm SEM of the number of animals in parentheses. ${ }^{*} \mathrm{p}<0.05$ as compared to NC (ANOVA and Student-Newman-Keuls as the post hoc test); ${ }^{* *} \mathrm{p}<0.05$ as compared to the same group before treatment (Student's paired $\mathrm{t}$ test)

Table 7: Urea, creatinine, AST and ALT levels in the serum of normal controls, alloxan-induced diabetic rats and diabetic rats before and after treatment with the tyramine (TYR), metformin (MET), or the combination of MET + TYR

\begin{tabular}{|c|c|c|c|c|c|}
\hline Group & & Urea $\left(\mathrm{mg} \mathrm{dL}^{-1}\right)$ & Creatinine $\left(\mathrm{mg} \mathrm{dL}^{-1}\right)$ & $\operatorname{AST}\left(\mathrm{U} \mathrm{L}^{-1}\right)$ & $\operatorname{ALT}\left(\mathrm{U} \mathrm{L}^{-1}\right)$ \\
\hline \multirow[t]{2}{*}{$\mathrm{NC}$} & B & $\begin{array}{l}19.6 \pm 0.56 \\
(12)\end{array}$ & $\begin{array}{l}0.4 \pm 0.03 \\
(14)\end{array}$ & $\begin{array}{l}86.0 \pm 4.04 \\
(16)\end{array}$ & $49.2 \pm 4.32$ \\
\hline & A & $21.1 \pm 0.88$ & $0.4 \pm 0.03$ & $70.4 \pm 2.75$ & $48.9 \pm 4.24$ \\
\hline \multirow[t]{2}{*}{ DC } & B & $\begin{array}{l}49.7 \pm 3.44 \\
(12)^{*}\end{array}$ & $\begin{array}{l}3.1 \pm 0.16 \\
(12)^{*}\end{array}$ & $\begin{array}{l}89.0 \pm 5.65 \\
(24)\end{array}$ & $\begin{array}{l}43.5 \pm 3.65 \\
(10)\end{array}$ \\
\hline & A & $42.6 \pm 6.27 *$ & $2.5 \pm 0.10^{*}$ & $73.2 \pm 7.94$ & $52.9 \pm 4.84$ \\
\hline \multirow[t]{2}{*}{ TYR 1} & B & $\begin{array}{l}42.0 \pm 4.74 \\
(12)^{*}\end{array}$ & $\begin{array}{l}2.6 \pm 0.19 \\
(13)^{*}\end{array}$ & $\begin{array}{l}73.4 \pm 4.20 \\
(14)\end{array}$ & $\begin{array}{l}46.0 \pm 3.15 \\
(21)\end{array}$ \\
\hline & A & $31.0 \pm 4.60 * * *$ & $1.9 \pm 0.16 * *$ & $55.6 \pm 5.30 * *$ & $38.0 \pm 2.82$ \\
\hline \multirow[t]{2}{*}{ TYR 2} & B & $\begin{array}{l}59.0 \pm 2.07^{*} \\
(6)\end{array}$ & $\begin{array}{l}2.3 \pm 0.32 \\
(06)^{*}\end{array}$ & $\begin{array}{l}86.9 \pm 10.19 \\
(8)\end{array}$ & $\begin{array}{l}52.3 \pm 4.06 \\
(12)\end{array}$ \\
\hline & A & $49.7 \pm 3.44 *$ & $1.4 \pm 0.20 * *$ & $83.9 \pm 13.44$ & $45.3 \pm 4.41$ \\
\hline \multirow[t]{2}{*}{ MET 50} & B & $\begin{array}{l}37.9 \pm 4.41 * \\
(12)\end{array}$ & $\begin{array}{l}3.1 \pm 0.14 * \\
(16)\end{array}$ & $\begin{array}{l}74.8 \pm 5.34 \\
(16)\end{array}$ & $\begin{array}{l}40.0 \pm 1.97 \\
(14)\end{array}$ \\
\hline & A & $26.3 \pm 3.13^{* *}$ & $1.5 \pm 0.07 * *$ & $44.6 \pm 4.76 * * *$ & $33.2 \pm 1.91$ \\
\hline \multirow[t]{2}{*}{ MET $50+$ TYR 1} & B & $\begin{array}{l}51.8 \pm 1.81 \\
(08)^{*}\end{array}$ & $\begin{array}{l}3.0 \pm 0.09 * \\
(8)\end{array}$ & $\begin{array}{l}74.0 \pm 7.44 \\
(11)\end{array}$ & $\begin{array}{l}33.2 \pm 1.36 \\
(11)\end{array}$ \\
\hline & A & $26.0 \pm 2.05^{* *}$ & $1.3 \pm 0.12 * *$ & $48.2 \pm 3.73 *, * *$ & $31.8 \pm 1.88$ \\
\hline \multirow[t]{2}{*}{ MET 50 + TYR 2} & B & $\begin{array}{l}28.5 \pm 3.47 \\
(08)^{*}\end{array}$ & $\begin{array}{l}3.1 \pm 0.24 \\
(05)^{*}\end{array}$ & $\begin{array}{l}78.8 \pm 9.05 \\
(5)\end{array}$ & $\begin{array}{l}34.8 \pm 2.19 \\
(5)\end{array}$ \\
\hline & A & $16.3 \pm 3.24 * *$ & $2.1 \pm 0.27 * *$ & $40.0 \pm 3.15 * * *$ & $29.1 \pm 3.57 *$ \\
\hline
\end{tabular}

Values represent mean \pm SEM for the number of animals in parentheses. $\mathrm{NC}=$ non-diabetic control animals. Diabetic animals were treated, orally for 5 days, with distilled water (DC) or tyramine (TYR 1 and $2 \mathrm{mg}$ ) and Metformin (MET $50 \mathrm{mg} \mathrm{kg}^{-1}$ ), alone or associated. B and A = diabetic animals before and after treatments. ${ }^{*} \mathrm{p}<0.05$ as compared to NC (ANOVA and Student-Newman-Keuls as the post hoc test), ${ }^{*} \mathrm{p}<0.05$ as compared to the same group before treatment (Student's paired t test)

area in the liver of diabetic rats was significantly decreased, as compared to normal controls and a similar picture was observed in diabetic rats treated with the lower dose of MSF. However, the treatment of diabetic rats with the higher MSF dose (100 mg kg-1) completely reversed the alloxan cytotoxicity and liver beta cells characteristics were not significantly different from the normal ones (Fig. 2).
The present work evaluated biochemical parameters, such as triglycerides, VLDL, cholesterol and glucose, in the serum of alloxan-induced diabetic rats, before and after the treatment with a semi-purified fraction from leaves of $C$. verticillata (methanol soluble fraction, MSF) and tyramine, a main bioactive constituent of this fraction. Our results showed that MSF significantly decreased serum glucose, total 
Table 8: Hemoglobin $\left(\mathrm{Hb}, 4 \mathrm{~g} \mathrm{dL}^{-1}\right)$ in vitro glycation from nondiabetic rats, in the presence of D-glicose $50 \mathrm{mM}$ and the methanol soluble fraction (MSF) from Cissus verticillata, as comparad to tyramine (TYR) and quercetine (QCT)

\begin{tabular}{lll}
\hline Sample & $\%$ HBA1c & \% Inibition \\
\hline Control & $8.74 \pm 0.50(05)$ & - \\
MSF & $5.55 \pm 1.00(04)^{*}$ & 36.6 \\
TYR & $5.21 \pm 0.89(05)^{*}$ & 40.4 \\
QCT & $4.25 \pm 0.28(04)^{*}$ & 51.3 \\
\hline
\end{tabular}

Blood from eight Wistar rats fasted for $12 \mathrm{~h}$ was collected from the abdominal aorta and used to prepare an erythrocyte pool $(3 \mathrm{ml}$ of blood from each animal). Then, samples of this hemoglobin solution were incubated, for determination of glycated hemoglobin in vitro. Control tubes contained only buffer, $\mathrm{Hb}\left(4 \mathrm{~g} \mathrm{dL}^{-1}\right)$ and D-glicose $(50$ $\mathrm{mM}$ ). MSF, TYR and QCT were incubated at concentrations of 50 $\mu \mathrm{g} / \mathrm{ml}$. Values represent mean \pm SEM of the number of samples in parentheses. ${ }^{*} \mathrm{p}<0.05$ as related to controls (ANOVA and StudentNewman-Keuls as the post hoc test)

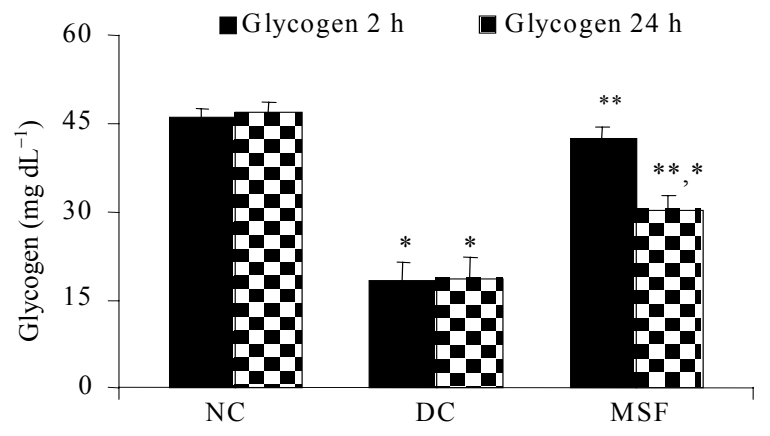

Fig. 1: Effect of the methanol soluble fraction (MSF) from Cissus verticillata, on hepatic glycogen, in diabetic rats Values represent mean \pm SEM of ten animals. $\mathrm{NC}=$ non-diabetic controls treated only with distilled water. Diabetic animals were treated with distilled water (DC) or MSF (100 $\mathrm{mg} \mathrm{kg}{ }^{-1}$ ), orally for ten days and after treatments livers were dissected and glycogen contents determined, 2 and $24 \mathrm{~h}$ after the addition of amyloglicosidase. ${ }^{*} \mathrm{p}<0.05$ as compared to $\mathrm{NC}$ (ANOVA and Student-Newman-Keuls as the post hoc test), ${ }^{* *}$ p $<0,05$ as compared to the same group before treatment (Student's paired t-test)

cholesterol and triglyceride levels, in diabetic rats. Similarly to MSF, tyramine also significantly decreased glycemia, TG and VLDL. The association of MSF or TYR with GLI did not decrease those values further. One interesting finding was the complete blockade of the increase in creatinine values, observed in diabetic animals after treatment with MSF or TYR. A similar effect was seen with GLI. Furthermore, a great decrease in AST values was observed, after the treatment of diabetic animals with the association of GLI+TYR.

Our results showed that the mechanism of the hypoglycemic action of MSF and TYR does not seem to be that of GLI, since no potentiation was observed

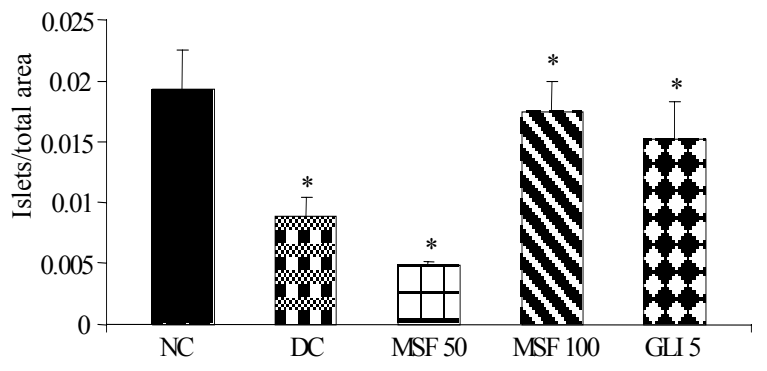

Fig. 2: Number of pancreatic islets in diabetic rats treated with the methanol soluble fraction (MSF) from Cissus verticillata and glibenclamide (GLI) Values represent mean \pm SEM of $6-8$ animals. $\mathrm{NC}=$ non-diabetic controls. Diabetic rats were treated, orally for 5 days, with distilled water (DC), MSF (50 and $\left.100 \mathrm{mg} \mathrm{kg}^{-1}\right)$, or GLI $\left(5 \mathrm{mg} \mathrm{kg}^{-1}\right)$ and five days after treatments the pancreas was dissected and stained with hematoxilin-eosin for the counting of the number of islets, by optic microscopy. ${ }^{*} \mathrm{p}<0.05$ as compared to NC (ANOVA and Student-Newman-Keuls as the post hoc test); ${ }^{* *} \mathrm{p}<0.05$ as compared to the same group before treatment (Student's paired t-test)

after the association of GLI+TYR. Glibenclamide also called glyburide is a sulfonylurea that has as its major action the increase in insulin release from the pancreas or an insulinotropic action ${ }^{[18]}$. Insulin secretion is controlled by the membrane potential of beta cells, which depends on the activity of ATP-sensitive $\mathrm{K}^{+}$ channels ( $\mathrm{K}_{\text {ATP }}$ channels). These channels close, following an increase in the cytoplasmic ATP/ADP ratio. This leads to membrane depolarization, opening of voltage-gated $\mathrm{Ca}^{2+}$ channels, elevation of the cytoplasmic $\mathrm{Ca}^{2+}$ concentration and stimulation of $\mathrm{Ca}^{2+}$ dependent exocytosis of the insulin-containing granules. These channels represent then a target for hypoglycemic sulfonylureas ${ }^{[19,20]}$.

Furthermore, we showed that the hyperglycemic effect of diazoxide, an ATP-dependent potassium $\left(\mathrm{K}_{\mathrm{ATP}}\right)$ channel agonist, was not reversed by MSF or TYR, suggesting again that their mechanism of action is not similar to that of GLI. Diazoxide is an antihypertensive drug which is known to open $\mathrm{K}_{\mathrm{ATP}}$ and to hyperpolarize plasma membranes, including those of pancreatic-beta cells, thus decreasing insulin secretion ${ }^{[21]}$. In this sense, its mechanism of action opposes that of GLI.

Recent reports demonstrated that the oral administration for 7 days, with doses of 100 and 200 $\mathrm{mg} \mathrm{kg} \mathrm{kg}^{-1}$ of the aqueous extract from C. verticillata, 
reduced hyperglycemia in alloxan-induced diabetic rats $^{[22]}$. The tea from this plant presents a hypoglycemic activity in normoglycemic rats and this effect is probably due to the presence of flavonoids ${ }^{[13]}$. Furthermore, a recent work showed that tyramine, a tracer amine also present in $C$. verticillata, at the dose of $26 \mu \mathrm{mol} \mathrm{kg}$, i.p., administered for 3 weeks to diabetic rats, resulted in decreased hyperglycemic responses ${ }^{[23]}$. The chronic exposure to tyramine, an amine oxidase substrate, led to an improvement of glucose tolerance in diabetic rats ${ }^{[16]}$. In addition, the acute exposure to tyramine reduced hyperglycemia and triglycerides in alloxan-diabetic rats ${ }^{[15]}$ and these results were similar to ours. In the present study, we also showed that tyramine decreased the percentage of glycated hemoglobin. Glycation of $\mathrm{Hb}$ has been implicated in nephropathy and retinopathy in diabetes mellitus and is primarily used to identify plasma glucose concentration over a prolonged period of time $^{[24]}$. Furthermore, MSF decreased lesion and increased the number of pancreatic beta cells, protecting cells against the alloxan-induced cytotoxicity.

Pancreatic islets can suffer functional and morphological alterations due to several factors, including drugs that produce free radicals, such as alloxan and streptozotocin ${ }^{[25]}$. Some reports indicate that the formation of superoxide and hydroxylradicals is responsible for the alloxan-induced cytotoxicity ${ }^{[26,27,28]}$. Immunohistochemical studies demonstrated that the pancreas from alloxan-induced diabetic animals showed a $70 \%$ reduction of beta cell areas. At the same time, there was an increase in the areas occupied by delta cells and no alteration in glucagon-producing cells ${ }^{[29]}$. Another study ${ }^{[30]}$ showed decreases in the number of insulin positive cells and increases in the number of cells expressing somatostatin in rats submitted to alloxan-induced diabetes. These authors did not observe any alteration regarding to glucagon producing cells. We also observed that the significant decrease in the liver glycogen content of diabetic rats were totally or partially blocked after MSF treatment. The antihyperglycemic activity of both MSF and TYR may be due to increased utilization of glucose. In diabetic rats, high glucose levels and decreased hepatic glycogen could be attributed to low availability of glycogen synthetase, as demonstrated elsewere ${ }^{[31,32,33]}$.

In order to clarify the mechanism of action of the hypoglycemic effect of $C$. verticillata, we studied the effects of the association of TYR plus MET on several biochemical parameters, in the serum of alloxaninduced diabetic rats. Unlikely the results observed with the association of GLI plus TYR, a clear potentiation was seen as far as the decrease in glucose levels is concerned, after the treatment of diabetic animals with the association of MET plus TYR. Under this experimental condition, values of glycemia were near normality. Our data suggest that the mechanism of hypoglycemia observed after MSF and TYR treatments of alloxan-induced diabetic rats is similar to that shown by MET.

Metformin is an oral hypoglycemic drug of the biguanide class and its mechanism of action remains elusive. The blood glucose-lowering action of the drug does not depend on the functioning of pancreatic cells. Currently proposed mechanisms of action include: a) reduced hepatic and renal gluconeogenesis; b) slowing of glucose absorption from the gastrointestinal tract, with increased glucose conversion to lactate by enterocytes; c) direct stimulation of glycolysis in tissues, with increased glucose removal from the blood; and d) reduction of plasma glucagon levels. As a matter of fact, a combination therapy with glibenclamide plus metformin is considered as an optimal and rational therapeutic treatment of patients with type 2 diabetes mellitus, giving better glycemic control than the monotherapy with either drug ${ }^{[34]}$.

It has been demonstrated that metformin alone mimics insulin's ability to increase receptor tyrosine kinase activity and stimulate phospholipase $\mathrm{C}^{[35]}$. More recently, MET was shown ${ }^{[36,37]}$ to activate the AMPactivated protein kinase cascade, via an adenine nucleotide-independent mechanism. Then, it is possible that the hypoglycemic activity of MSF and TYR involves a similar mechanism of action and at least in part these drugs may act by activating the AMPK. Furthermore, it has been demonstrated that amine oxidase substrates inhibit the lipolytic activity in rat adipocytes. These data suggest that inhibition of lipolysis is a novel insulin-like effect of tyramine that is mediated by hydrogen peroxide, generated during amine oxidation $^{[15,16]}$.

In conclusion, our results showed that the oral administration of the methanol soluble fraction from $C$. verticillata had a beneficial effect on the rat diabetic state, reducing hyperglycemia as well as the hyperlipidemia, similarly to that presented by tyramine, a bioactive constituent of the plant. Furthermore, at least in part, the hypoglycemic activity of MSF and tyramine is similar to that shown by MET, probably increasing pancreatic insulin and opening $\mathrm{K}^{+}$channels. Data in the literature relate that flavonoids and tyramine possess both hypoglycemic and hypotriglyceridemic effects in diabetic animals ${ }^{[23,38]}$. Therefore, studies with flavonoids and tyramine, as well as with other constituents present in the plant, are underway to 
further elucidate their mechanisms of action and involvement with the putative anti-diabetic properties of C. verticillata.

\section{ACKNOWLEDGEMENTS}

The authors are grateful to the technical assistance of Ms. M. Vilani Rodrigues Bastos and to Prof. M.O.L.Viana for the orthographic revision of the manuscript. The work had the financial support from the Brazilian National Research Council (CNPq).

\section{REFERENCES}

1. Davis, S.N., 2006. Insulin, Oral Hypoglycemic Agents and the Pharmacology of the Endocrine Pancreas. In: Goodman and Gilmans the Pharmacological Basis of Therapeutics. Brunton, L.L. (Ed.). McGraw-Hill, New York, pp: 1613-1645.

2. Grover, J.K., V. Vats, S.S. Rathi and R. Dawar, 2001. Traditional Indian anti-diabetic plants attenuate progression of renal damage in streptozotocin induced diabetic mice. J. Ethnopharmacol., 76: 233-238.

3. Lino, C.S., J.P. Diógenes, B.A. Pereira, R.A. Faria, M. Andrade-Neto and R.S. Alves et al., 2004. Antidiabetic activity of Bauhinia forficata extracts in alloxan-diabetic rats. Biol. Pharm. Bull., 27: 125-127.

4. Quilez, A.M., M.T. Saenz, M.D. Garcia and R. de la Puerta, 2004. Phytochemical analysis and anti-allergic study of Agave intermixta Trel. and Cissus sicyoides L. J. Pharm. Pharmacol., 56: 1185-1189.

5. Garcia, M.D., A.M. Quilez, M.T. Saenz, M.E. Martinez-Dominguez and R. de la Puerta, 2000. Anti-inflammatory activity of Agave intermixta Trel. and Cissus sicyoides L., species used in the Caribbean traditional medicine. J. Ethnopharmacol., 71: 395-400.

6. Beltrame, F.L., A.G. Ferreira and D.A. Cortez, 2002. Coumarin glycoside from Cissus verticillata. Nat. Prod. Lett., 16: 213-216.

7. Pepato, M.T., A.M. Baviera, R.C. Vendramini, M.P. Perez, I.C. Kettelhut, I.L. Brunetti, 2003. Cissus verticillata (princess vine) in the long-term treatment of streptozotocin diabetic rats. Biotechnol. Applied Biochem., 37: 15-20.

8. Panthong, A., W. Supraditaporn, D. Kanjanapothi, T. Taesotikul and V. Reutrakul, 2006. Analgesic, anti-inflammatory and venotonic effects of Cissus quadrangularis Linn. J. Ethnopharmacol., 26: 1-7.
9. Medeiros, A.C.C., A.M.R. Lacerda, T.G. Vale and G.S.B. Viana, 2002. Efeitos analgésicos do extrato aquoso de Cissus sicyoides L. (abstract ). XVII Simpósio de Plantas Medicinais do Brasil, Cuiabá-MT.

10. Lino, C.S, T.P. Sales, C.P. Leite, F.S.O. Alexandre, E.R. Silveira and M.G.R. Queiroz, et al. 2006. Atividade Analgésica da Fração Solúvel de Cissus sicyoides e da tiramina. Simpósio Brasileiro de Plantas Medicinais. Salvador-Ba, In Livro de resumos.

11. Panthong, A., W. Supraditapom, D. Kanjanapothi, T. Taesotikul and V. Reutrakul, 2007. Analgesic, anti-inflammatory and venotonic effects of Cissus quadrangularis Linn. J. Ethnopharmacol., 110: 264-270.

12. Beltrame, F.L., J.L. Sartoretto, R.B. Bazotte, R.N. Cuman and D.A.G. Cortez, 2001. Estudo fitoquímico e avaliação do efeito antidiabético do Cissus verticillata L (Vitaceae). Química Nova, 24: 783-785.

13. Barbosa, W.L.R., W.R.A.S. Santos, L.N. Pinto and I.C.C. Tavares, 2002. Flavonóides de Cissus verticillata e a atividade hipoglicemiante do chá de suas folhas. Rev. Bras. Farmacognosia., 12: 13-15.

14. Alexandre, F.S.O., 2007. Análise fitoquímica de plantas do Ceará: Potencial farmacológico de Cissus verticillata e composição volátil de Myrcia $s p$. Dissertação de Mestrado em Química Orgânica, Universidade Federal do Ceará, pp: 111.

15. Morin, N., V. Visentin, D. Calise, L. Marti, A. Zorzano and X. Testar et al., 2002. Tyramine stimulates glucose uptake insulin-sensitive tissues in vitro and in vivo via its oxidation by amine oxidases. J. Pharmacol., 303: 1238-1247.

16. Visentin, V., P. Marq, S. Bour, C. Subra, D. Prevot and N. Morin et al., 2003. Effect of prolonged treatment with tyramine on glucose tolerance in streptozotocin-induced diabetic rats. J. Physiol. Biochem., 59: 225-232.

17. Sales, T.P., C.S. Lino, J.F. Magalhães, F.S.A. Oliveira, V.R. Bastos, E.R. Silveira and M.G.R. Queiroz et al., 2005. Atividade hipoglicemiante e hipolipemiante da fração semipurificada de Cissus verticillata. I Reunião Regional da Sociedade Brasileira de Plantas Medicinais (SBPM/NE), Fortaleza-CE.

18. Fuhlendorff, J., P. Rorsman, H. Kofod, C.L. Brand, B. Rolin, P. MacKay, R. Shymko and R.D. Carr, 1998. Stimulation of insulin release by repaglinide and glibenclamide involves both common and distinct processes. Diabetes, 47: 345-351. 
19. Ashcroft, F.M. and P. Rorsman, 1989. Electrophysiology of the $\beta$ cell. Prog. Biophys. Molec. Biol., 54: 87-144. 20.

20. Inagaki, N., T. Gonoi, J.P. Clement, N. Namba, J. Inazawa, G. Gonzalez, L. Aguilar-Bryan, S. Seino and J. Bryan, 1995. Reconstitution IATP: An inward rectifier subunit plus the sulphonylurea receptor. Science, 270: 1166-1170.

21. Raju, B. and P. Cryer, 2005. Mechanism, temporal patterns and magnitudes of the metabolic responses to the $\mathrm{K}_{\mathrm{ATP}}$ channel agonist diazoxide. Am. J. Physiol. Endocrinol. Metab., 288: E80-E85.

22. Viana, G.S.B., A.C.C. Medeiros, A.M.R. Lacerda, L.K.A.M. Leal, T.G. Vale and F.J.A. Matos, 2004. Hypoglycemic and anti-lipemic effects of the aqueous extract from Cissus verticillata. BMC Pharmacol., 4: 1-7.

23. Visentin, V., S. Bour, J. Boucher, D. Prevot, P. Valet and C. Ordener et al., 2005. Glicose handling in streptozotocin-induced diabetic rats is improved by tyramine but not the amine oxidase inhibitor semicarbazide. Eur. J. Pharmacol., 522: 139-146.

24. Baynes, J. and M.H. Doniniczac, 2000. Bioquímica Médica. Ed. Manole, São Paulo.

25. Montillapl, V.J.F., I.F. Tnez, M.C. Munoz de Agueda, M.E. Valdevira and E.S. Cabrera, 1998. Oxidative stress in diabetic rats induced by streptozotocin:Protective effects of melatonin. J. Pineal. Res., 25: 94-100.

26. Waguri, M., K. Yamamoto, J.I. Miyagawa, Y. Tochino, K. Yamamori, Y. Kajimoto, H. Nakajima, H. Watada, Y. Yamasaki, T. Hanafusa and Y. Matswzawa, 1997. Demonstration of two different processes of $\beta$ cells regeneration in a new diabetic mouse model induced by selective perfusion of alloxan. Diabetes, 46: 1281-1290.

27. Ahrén, B. and G. Sundkvist, 1995. Long-term effects of alloxan in mice. Int. J. Pancreatol. 7: 197-201.

28. Zhang, H., J.M. Zdolsek and U.T. Brunk, 1992. Alloxan cytotoxicity involves lysossomal damage. Acta Pathol. Microbiol. Immunol. Scand., 100: 309-316.

29. Rastogik, S., L. Lickley, M. Jokay, S. Efendic and M. Vranic, 1990. Paradoxical reduction in pancreatic glucagon with normalization of somatostatin and decrease in insulin in normoglycemic alloxan-diabetic dogs: A putative mechanism of glucagon irresponsiveness to hypoglycemia. Endocrinology, 126: 1096-1104.
30. Lima, M.A., L.M.B. Lima, D.P.C. Rita, F.C. Navarro, R.S. Tatsukawa, G.A. Pereira, L.C. Reis, M.E.A. Abreu and M.F. Borges, 2001. Quantitative analysis of cells of the pancreatic islets in rats under effect of alloxan. Medicina, Ribeirão Preto, 34: 308-314.

31. Goldstein, S., A. Simpson and P. Saenger, 1990. Hepatic drug metabolism increase in poorly controlled insulin dependent diabetes mellitus. Acta Endocri., 12: 3550-3558.

32. Mathieu, B. and S. Willey, 1984. The hepatic defect in glycogen synthesis in chronic diabetes involves component of synthase phosphatase. Biochem. J., 21: 7427-7435.

33. El-Missiry, M.A. and A.M. El Gindy, 200. Amelioration of alloxan induced diabetes mellitus and oxidative stress in rats by oil of Eruca sativa seeds. Ann. Nutr. Met., 44: 97-100.

34. DeRosa, G., 2006. Glibenclamide plus metformin combination tablets are effective, convenient and well tolerated in the treatment of type 2 diabetes mellitus. Drugs and Therapy Perspectives, 22: 1-6.

35. Stith, B.J., M.L. Goalstone, R. Espinoza, C. Mossel, D. Roberts and N. Wiernsperger, 1996. The antidiabetic drug metformin elevates receptor tyrosine kinase activity and inositol 1,4,5trisphosphate mass in Xenopus oocytes. Endocrinol., 137: 2990-2999.

36. Hawley, S.A., A.E. Gadalla, G.S. Olsen and G. Hardie, 2002. The antidiabetic drug metformin activates the AMP-activated protein kinase cascade via an adenine nucleotide-independent mechanism. Diabetes, 51: 2420-2425.

37. Zou, M.H., S.S. Kirkpatrick, B.J. Davis, J.S. Nelson, W.G. Wiles IV, U. Schlattner, D. Neumann, M. Brownlee, M.B. Freeman and M.H. Goldman, 2004. Activation of the AMPactivated protein kinase by the anti-diabetic drug metformin in vivo. J. Biol. Chem., 279: 43940-43951.

38. Mori, T., Y. Nishikawa, Y. Takata, N. Kashiuchi and N.J. Ishira, 2001. Effect of insulin leaf extraction on development of diabetes-Comparison between normal, streptozotocin-induced diabetic rats and hereditary diabetic mice. Japanese Soc. Nutr. Food Sci., 54: 197-203. 